ISSN 0258-7122

Bangladesh J. Agril. Res. 37(4): 645-652, December 2012

\title{
INFLUENCE OF SULPHUR ON MORPHO-PHYSIOLOGICAL AND YIELD PARAMETERS OF RAPESEED (Brassica campestris L.)
}

\author{
FERDOUSI BEGUM ${ }^{1}$, FEROZA HOSSAIN ${ }^{2}$ \\ MD. RAFIQUL ISLAM MONDAL ${ }^{3}$
}

\begin{abstract}
Field experiments were conducted at the Central Research Station of Bangladesh Agricultural Research Institute (BARI), Joydebpur, Gazipur during the period from November to February in 2004-05 and 2005-06 to evaluate the effect of different levels of sulphur $(0,20,40,60$, and $80 \mathrm{~kg} / \mathrm{ha}$ ) on rapeseed variety BARI Sarisha-15. Results showed that the most of the growth parameters and yield attributes were significantly influenced by different doses of sulphur. The growth parameters, yield and yield contributing characters were increased with the increasing levels of sulphur fertilizer up to $60 \mathrm{~kg} \mathrm{~S} / \mathrm{ha}$ and with the doses beyond that were found to decrease. All growth parameters like plant height, leaf area, dry matter accumulation, leaf area index, crop growth rate, net assimilation rate, and relative growth rate and all yield components, such as number of siliquae per plant, seeds per siliqua, 1000-seed weight and seed yield per plant were found maximum from the treatment with $60 \mathrm{~kg} \mathrm{~S} / \mathrm{ha}$, which was at par with $80 \mathrm{~kg}$ S/ha. The highest seed yield (1990 and $1896 \mathrm{~kg} / \mathrm{ha}$ ) were found when S was used @ 60 kg/ha. The same treatment gave $24.71 \%$ and $24.32 \%$ higher seed yield than the control treatment, which were statistically identical with dose at $80 \mathrm{~kg} / \mathrm{ha}$ of sulphur in both the years.
\end{abstract}

Keywords: Rapeseed, sulphur, morpho- physiological parameters, and yield parameters.

\section{Introduction}

Mustard/rapeseed is an important oilseed crop of Bangladesh and its oil is mainly used as edible oil. In Bangladesh, campestris is mainly cultivated and another species B. juncea is also cultivated for edible oil (Kaul and Das, 1986). Edible oil plays a very important role in human nutrition. As a high-energy component of food, edible oils are important for meeting the calorie requirements. Bangladesh has been facing acute shortage of edible oil for the last several decades. Our internal production can meet only about $21 \%$ of our consumption. The rest $79 \%$ is met from the import. To meet up the growing demand of oilseed, it is urgent to ensure its higher production. It is almost impossible to increase production by

\footnotetext{
${ }^{1}$ Sernior Scientific Officer Oilseed Research Centre, BARI, ${ }^{2}$ Professor, Department of Botani, Jahangirnagar University, Dhaka, ${ }^{3}$ Director General, Bangladesh Agricultural Research Institute (BARI), Gazipur, Bangladesh.
} 
increasing area because of crop competitions. Therefore, production per unit area can be increased by adopting improved technology and inputs. Mustard is responsive to sulphur in comparison to other crops. Sulphur is essential for the growth and development of all crops. Oleiferous Brassica crops in general have high sulphur requirement owing to higher seed and oil yield (Aulakh et al., 1980; Sing and Shahu, 1986).

Sulphur is the key component of balanced nutrient application for higher yields and superior quality produce. In general, about $97 \%$ soils of Bangladesh are deficient in sulphur and this deficiency is becoming acute day by day due to extensive use of sulphur free fertilizers and intensive crop production. So to increase total production, increased yield per unit area of land is a must in Bangladesh. This increase can be achieved by using improved varieties and adopting improved management practices in the field level (Mondal and Wahhab, 2001). However, no data are available about the effect of sulphur on the physiological aspects of rapeseed as well as biological and economic yields. Therefore, there is a good scope to work on the morphological and yield aspects of rapeseed, especially with sulphur fertilizer.

\section{Materials and Method}

The field experiments were conducted at the Central Research Station of Bangladesh Agricultural Research Institute (BARI), Joydebpur, Gazipur during the period from November 2004 to February 2006.The experimental field was a piece of well drained high land with moderately even topography. The area belongs to Madhupur tract $(\mathrm{AEZ}, 28)$, clay loam in texture, having low organic matter, moderately slow permeability, and deficient in nitrogen, phosphorus, potassium, and sulphur in comparison with the standard nutrient status. The soil is acidic in nature with $\mathrm{p}^{\mathrm{H}}$ ranging from 5.9 to 6.1. The sulphur levels of the experimental site were $8.00 \mathrm{ppm}$ and $9.00 \mathrm{ppm}$, which were quite below the critical level for mustard crop (Table 1).

Table 1. Initial soil properties of the experimental field of Bangladesh agricultural Research Institute, Joydebpur, Gazipur.

\begin{tabular}{lcccc}
\hline \multicolumn{1}{c|}{ Properties } & $2004-05$ & $2005-06$ & Critical level \\
\hline $\mathrm{K}(\mu \mathrm{g} / \mathrm{ml})$ & 0.16 & 0.12 & 0.20 \\
$\mathrm{NH}_{4}-\mathrm{N}(\mu \mathrm{g} / \mathrm{ml})$ & 0.25 & 0.45 & 75.00 \\
$\mathrm{P} \quad$ " & 13.00 & 12.00 & 14.00 \\
$\mathrm{~S} \quad$ " & 8.00 & 9.00 & 14.00
\end{tabular}

The experiments were laid out in a randomized complete block design (factorial) with three replications having plant distances $30 \mathrm{~cm}$ and $5 \mathrm{~cm}$ respectively. Plot size was $2.4 \mathrm{~m} \times 3.0 \mathrm{~m}$. Among the different varieties of rapeseed/mustard, a newly developed high yielding variety (BARI Sharisa-15) 
was selected for the study. Recommended doses of N, P, K, Zn, and B fertilizers except sulphur, intercultural operations were applied and plant protection measures were done accordingly (Mondal and Wahhab, 2001). Sulphur was applied at the rate of $0,20,40,60$, and $80 \mathrm{~kg} / \mathrm{ha}$ in the form of gypsum as basal dose.

Data were collected on growth parameters i.e., plant height, leaf area, dry matter accumulation at different growth stages starting from 18 days after emergence at 10 days interval upto 78 days. Leaf area index, crop growth rate, net assimilation rate, and relative growth rate were calculated. Data were also collected on yield parameters i.e., number of siliquae/plant, siliqua length, seeds/siliqua, 1000-seed weight, seed yield/plant, seed yield per hectare, and stover yield per hectare after harveste. collected data were statistically analyzed and treatment means were compared by least significant difference test (Steel and Torrie, 1960).

\section{Results and Discussion}

\section{Effect of sulphur on morphological parameters}

Sulphur application induced significant increase in the physiological parameters and seed yield (Tables 2, 3, 4, and 5). The $S_{3}(60 \mathrm{~kg} \mathrm{~S} / \mathrm{ha}$ ) treatment produced the tallest plant $(104.5 \mathrm{~cm}$ and $102.8 \mathrm{~cm})$ in both years, while it was statistically at par with $\mathrm{S}_{4}$ treatment $(80 \mathrm{~kg} / \mathrm{ha}$ ) in first year and significantly different from other treatments in second year (Table 2). Sulphur generally tends to increase plant height. It enhances cell division, elongation, and expansion, but the application of sulphur beyond $60 \mathrm{~kg} / \mathrm{ha}$ did not influence plant height. This result agrees well with those of Nepalia (2005); Singh and Meena (2004) on mustard.

Table 2. Effect of sulphur fertilization on physiological parameters of rapeseed var. BARI Sarisha-15.

\begin{tabular}{l|cc|cc|c|c|cc}
\hline Treatment & \multicolumn{2}{|c|}{$\begin{array}{c}\text { Plant height } \\
\text { (78 DAE) }\end{array}$} & \multicolumn{2}{c|}{$\begin{array}{c}\text { Leaf number } \\
\text { per plant } \\
(58 \text { DAE) }\end{array}$} & \multicolumn{2}{c|}{$\begin{array}{c}\text { Leaf area index } \\
\text { (LAI) } \\
\text { (58 DAE) }\end{array}$} & \multicolumn{2}{c}{$\begin{array}{c}\text { Dry matter per } \\
\text { plant } \\
(68 \mathrm{DAE})\end{array}$} \\
\cline { 2 - 10 } & Ist year & $2^{\text {nd }}$ year & Ist year & $2^{\text {nd }}$ year & Ist year & $2^{\text {nd }}$ year & Ist year & $2^{\text {nd }}$ year \\
\hline $\mathrm{S}_{0}$ & 97.6 & 95.5 & 17.1 & 17.6 & 1.56 & 1.66 & 9.43 & 10.25 \\
$\mathrm{~S}_{1}$ & 99.4 & 97.7 & 17.4 & 17.8 & 1.59 & 1.69 & 9.83 & 10.91 \\
$\mathrm{~S}_{2}$ & 102.7 & 100.1 & 19.0 & 19.5 & 1.85 & 1.90 & 10.92 & 12.35 \\
$\mathrm{~S}_{3}$ & 104.5 & 102.8 & 20.6 & 21.3 & 2.13 & 2.21 & 12.65 & 14.69 \\
$\mathrm{~S}_{4}$ & 103.1 & 99.9 & $19.3 \mathrm{~b}$ & 19.7 & 2.01 & 1.98 & 11.36 & 12.92 \\
\hline $\mathrm{CV} \mathrm{( \% )}$ & 2.18 & 2.02 & 7.63 & 9.85 & 7.56 & 9.83 & 3.96 & 5.2 \\
LSD (.05) & 1.48 & 1.33 & 0.95 & 1.26 & 0.12 & 0.12 & 0.29 & 0.261 \\
\hline
\end{tabular}

$\mathrm{S}_{0}=0 \mathrm{~kg} / \mathrm{ha}, \mathrm{S}_{1}=20 \mathrm{~kg} / \mathrm{ha}, \mathrm{S}_{2}=40 \mathrm{~kg} / \mathrm{ha}, \mathrm{S}_{3}=60 \mathrm{~kg} / \mathrm{ha}, \mathrm{S}_{4}=80 \mathrm{~kg} / \mathrm{ha}$ 
Table 3. Effect of sulphur fertilization on physiological parameters and seed yield of rapeseed var. BARI Sarisha-15.

\begin{tabular}{l|c|c|c|c}
\hline \multirow{2}{*}{ Treatment } & \multicolumn{2}{|c|}{$\begin{array}{c}\text { Crop growth rate (CGR) } \\
\left(\mathrm{g} / \mathrm{m}^{2} / \text { day) }\right.\end{array}$} & \multicolumn{2}{c}{$\begin{array}{c}\text { Net assimilation rate (NAR) } \\
\left(\mathrm{g} / \mathrm{m}^{2} / \text { day }\right)\end{array}$} \\
\cline { 2 - 5 } & $\begin{array}{c}\text { Ist year } \\
(48-58 \mathrm{DAE})\end{array}$ & $\begin{array}{c}2^{\text {nd }} \text { year } \\
(48-58 \mathrm{DAE})\end{array}$ & $\begin{array}{c}\text { Ist year } \\
(38-48 \mathrm{DAE})\end{array}$ & $\begin{array}{c}2^{\text {nd }} \text { year } \\
(38-48 \mathrm{DAE})\end{array}$ \\
\hline $\mathrm{S}_{0}$ & 18.60 & 18.91 & 13.60 & 16.59 \\
$\mathrm{~S}_{1}$ & 18.92 & 19.81 & 13.83 & 16.71 \\
$\mathrm{~S}_{2}$ & 20.09 & 20.12 & 14.29 & 16.73 \\
$\mathrm{~S}_{3}$ & 20.34 & 22.24 & 15.40 & 17.40 \\
$\mathrm{~S}_{4}$ & 17.64 & 20.51 & 14.61 & 16.55 \\
\hline $\mathrm{CV}(\%)$ & 6.09 & 8.59 & 6.21 & 3.99 \\
$\mathrm{LSD}(.05)$ & 1.54 & 1.17 & 0.59 & 0.45 \\
\hline
\end{tabular}

$\mathrm{S}_{0}=0 \mathrm{~kg} / \mathrm{ha}, \mathrm{S}_{1}=20 \mathrm{~kg} / \mathrm{ha}, \mathrm{S}_{2}=40 \mathrm{~kg} / \mathrm{ha}, \mathrm{S}_{3}=60 \mathrm{~kg} / \mathrm{ha}, \mathrm{S}_{4}=80 \mathrm{~kg} / \mathrm{ha}$

Number of leaves per plant and leaf area index tended to increase with the application of sulphur up to $60 \mathrm{~kg} / \mathrm{ha}\left(\mathrm{S}_{3}\right)$ at $58 \mathrm{DAE}$. Further increase in sulphur rate tended to depress number of leaves per plant possibly due to sulphur becoming unavailable to plants or might have created the toxic effect on mustard. This result is agreement with of those of Mohan and Sharma (1992). Nasreen et al., 2003 reported that number of leaves of sunflower plant tended to increase with the application of sulphur up to $60 \mathrm{~kg} / \mathrm{ha}$ and then declined. Sulphur at $\mathrm{S}_{3}$ $(60 \mathrm{~kg} / \mathrm{ha})$ also enhanced LAI over other treatments. The positive effect of sulphur on LAI has also been reported in opium poppy (Intodia and Sahu, 2005); in rice ( Ali et al., 2004); in summar green ( Kumawat et al., 2005). Besides, the treatment $\mathrm{S}_{3}(60 \mathrm{~kg} \mathrm{~S} / \mathrm{ha}$ ) showed $25.4 \%$ and $30.2 \%$ more dry weight per plant over those of the control at 68 DAE in both the years (Table 2). Increase in total drymatter production at this growth phase was possibly due to increase in photosynthetic rate. The result confirms the findings of Singh and Singh (1984). Similar result was observed by Ali et al. (1995) in mustard. Dry matter production in mustard at Sulphur @ 60 kg/ha was also reported by Singh and Meena (2004). The highest crop growth rate CGR (20.34 and 22.24) were obtained with the treatment $S_{3}(60 \mathrm{~S} \mathrm{~kg} / \mathrm{ha})$ at 48-58 DAE, which was followed by $S_{2}(40 \mathrm{~kg} / \mathrm{ha}$ ) in both the years (Table 3$)$. Net assimilation rate (NAR) varied significantly among the treatments. Among the sulphur treatments, the $\mathrm{S}_{3}(60 \mathrm{~kg} / \mathrm{ha})$ treatment showed the highest NAR (15.40 and 17.40$)$ at 38-48 DAE in both the years (Table 3). The gradual decrease of NAR with plant's age was also observed in jute (Begum, 1998). Maity et al. (2003) observed an increase of NAR in groundnut and sunflower with the sulphur treatments up to $30 \mathrm{~kg} / \mathrm{ha}$. 


\section{Effects of sulphur on yield contributing parameters}

Number of branches per plant significantly varied among the $S$ fertilization treatments. Maximum number of branches per plant (5.9 and 5.9) was observed from the treatment $S_{2}(40 \mathrm{~kg} \mathrm{~S} / \mathrm{ha})$ in first year and treatment $S_{3}(60 \mathrm{~kg} / \mathrm{ha})$ treatment in second year (Table 4 ). Rana and Rana (2003) observed an increase in the number of branches per plant in mustard with the application of $60 \mathrm{~kg} / \mathrm{ha} \mathrm{S}$. Similar findings were also reported by Nepalia (2005). Maximum number of siliquae per plant (96.7 and 95.9) was observed at $60 \mathrm{~kg} / \mathrm{ha}$ of sulphur $\left(\mathrm{S}_{3}\right)$ and the lowest number (60.5 and 59.7) was recorded from the control treatment in both the years (Table 4). The siliqua per plant of mustard significantly increased up to $50 \mathrm{~kg} / \mathrm{ha}$ which was reported by Kumar et al., 2002.

The $\mathrm{S}$ fertilization at $80 \mathrm{~kg} / \mathrm{ha}$ produced the highest number of seeds per siliqua (18.6), which was also at par with $S_{3}(60 \mathrm{~kg} \mathrm{~S} / \mathrm{ha})$ and $S_{2}(40 \mathrm{~kg} \mathrm{~S} / \mathrm{ha})$ in this respect. Increased number of seeds per siliqua in mustard was reported by Rana and Rana (2003). Similar results were also reported by Singh et al. (2002). The $\mathrm{S}_{3}(60 \mathrm{~kg} \mathrm{~S} / \mathrm{ha}$ ) showed the highest seed yield per plant (18.91 g and 18.73 g). The $\mathrm{S}_{3}$ showed $40.19 \%$ and $40.79 \%$ higher seed yield than the control in both the years (Table 5). Sulphur application significantly increased 1000-seed weight over $\mathrm{S}_{0}$ level. Among $\mathrm{S}$ treatments, the highest 1000- seed weight (3.35 g and $3.37 \mathrm{~g})$ were shown by $\mathrm{S}_{3}(60 \mathrm{~kg} \mathrm{~S} / \mathrm{ha})$, which was at par with $\mathrm{S}_{4}(80 \mathrm{~kg} \mathrm{~S} / \mathrm{ha})$ and were $7.16 \%$ and $5.64 \%$ higher than that of control in both the years (Table 5). The improved nutritional environment as a result of increased S supply might have favourably influenced the carbohydrate metabolism. This favourable effect led to increased translocation of photosynthates towards seeds resulting in formation of bold seeds. Rathore and Manohar (1989) also reported similar results.

The seed yield/ha significantly increased with increasing level of S up to 60 $\mathrm{kg} / \mathrm{ha}$ and thereafter declined in both the years. Among $\mathrm{S}$ treatments, the highest seed yield/ha (1990 kg/ha and $1826 \mathrm{~kg} / \mathrm{ha})$ were shown by $\mathrm{S}_{3}(60 \mathrm{~kg} \mathrm{~S} / \mathrm{ha})$ in both the years, which was at par with $\mathrm{S}_{4}\left(80 \mathrm{~kg} \mathrm{~S} / \mathrm{ha}\right.$ and $\left.\mathrm{S}_{2} 40 \mathrm{~kg} \mathrm{~S} / \mathrm{ha}\right)$ and $24.32 \% 21.46 \%$ higher than that of control (Table 5). Among S treatments, the highest stover yield (4666 kg and $4281 \mathrm{~kg} / \mathrm{ha}$ ) was shown at $\mathrm{S}_{3}(60 \mathrm{~kg} / \mathrm{ha})$ in the both the years, which was $26.83 \%$ and $27.98 \%$ higher than that of control. (Table 5).

Yield capacity of mustard is the function of the number of plants per unit area, number of seeds/siliqua, seed yield/plant, and 1000-seed weight. The highest seed yield with the application of sulphur might be due to increased formation of reproductive structure for sink strength and increased production of assimilates to fill the economically important sink. Application of sulphur through gypsum significantly increased the seed yield in mustard as reported by Dubey et al. (1993). 
From the results of the experiments, it can be concluded that application of sulphur fertilizer to rapeseed var. BARI Sarisha-15, the stimulated growth of plants which had significant effects on plant height, leaf area index, crop growth rate, and net assimilation rate. Most of the growth parameters, yield, and yield contributing characters were increased with the increasing levels of sulphur fertilizer up to $60 \mathrm{~kg} \mathrm{~S} / \mathrm{ha}$ and with the doses beyond that were found to decrease the parameters .So, it may be concluded that $60 \mathrm{~kg} \mathrm{~S} / \mathrm{ha}$ may be used for increasing physiological parameters and seed yield of the rapeseed variety BARI Sarisha- 15.

Table 4. Effect of sulphur fertilization on yield parameters of rapeseed var. ARI Sarisha- 15.

\begin{tabular}{|c|c|c|c|c|c|c|c|c|}
\hline \multirow[b]{2}{*}{ Treatment } & \multicolumn{2}{|c|}{$\begin{array}{c}\text { Number of } \\
\text { branches per } \\
\text { plant } \\
\text { (At harvest) }\end{array}$} & \multicolumn{2}{|c|}{$\begin{array}{l}\text { Number of } \\
\text { siliqua per } \\
\text { plant }\end{array}$} & \multicolumn{2}{|c|}{$\begin{array}{l}\text { Siliqua } \\
\text { length } \\
(\mathrm{cm})\end{array}$} & \multicolumn{2}{|c|}{$\begin{array}{c}\text { Number of seeds/ } \\
\text { siliqua }\end{array}$} \\
\hline & $\begin{array}{l}\text { Ist } \\
\text { year }\end{array}$ & $2^{\text {nd }}$ year & $\begin{array}{l}\text { Ist } \\
\text { year }\end{array}$ & $\begin{array}{l}2^{\text {nd }} \\
\text { year }\end{array}$ & $\begin{array}{l}\text { Ist } \\
\text { year }\end{array}$ & $\begin{array}{l}2^{\text {nd }} \\
\text { year }\end{array}$ & $\begin{array}{l}\text { Ist } \\
\text { year }\end{array}$ & $2^{\text {nd }}$ year \\
\hline $\mathrm{S}_{0}$ & 3.7 & 3.6 & 60.5 & 59.7 & 4.1 & 4.1 & 17.1 & 16.9 \\
\hline $\mathrm{S}_{1}$ & 4.1 & 4.1 & 68.2 & 66.4 & 4.4 & 4.3 & 17.4 & 17.1 \\
\hline $\mathrm{S}_{2}$ & 5.9 & 5.1 & 85.9 & 85.1 & 4.7 & 4.6 & 18.7 & 18.4 \\
\hline $\mathrm{S}_{3}$ & 5.5 & 5.9 & 96.7 & 95.9 & 5.5 & 5.3 & 18.6 & 18.2 \\
\hline $\mathrm{S}_{4}$ & 5.2 & 5.4 & 90.7 & 90.0 & 4.9 & 4.8 & 18.4 & 18.6 \\
\hline CV (\%) & 7.54 & 5.83 & 4.69 & 3.23 & 6.29 & 7.4 & 5.2 & 4.5 \\
\hline LSD (.05) & 0.25 & 0.19 & 2.52 & 1.71 & 0.18 & 0.25 & 0.83 & 0.55 \\
\hline
\end{tabular}

$\mathrm{S}_{0}=0 \mathrm{~kg} / \mathrm{ha}, \mathrm{S}_{1}=20 \mathrm{~kg} / \mathrm{ha}, \mathrm{S}_{2}=40 \mathrm{~kg} / \mathrm{ha}, \mathrm{S}_{3}=60 \mathrm{~kg} / \mathrm{ha}, \mathrm{S}_{4}=80 \mathrm{~kg} / \mathrm{ha}$

Table 5. Effect of sulphur fertilization on yield parameters and seed yield of rapeseed var. BARI sarisha-15.

\begin{tabular}{|c|c|c|c|c|c|c|c|c|}
\hline \multirow[t]{2}{*}{ Treatment } & \multicolumn{2}{|c|}{$\begin{array}{l}\text { Seed yield per } \\
\text { plant (g) }\end{array}$} & \multicolumn{2}{|c|}{$\begin{array}{l}\text { 1000-seed wt } \\
\text { (g) }\end{array}$} & \multicolumn{2}{|c|}{$\begin{array}{c}\text { Seed yield/ hectare } \\
(\mathrm{kg})\end{array}$} & \multicolumn{2}{|c|}{$\begin{array}{l}\text { Stover yield } \\
\text { (kg) }\end{array}$} \\
\hline & Ist year & $2^{\text {nd }}$ year & Ist year & $2^{\text {nd }}$ year & Ist year & $2^{\text {nd }}$ year & Ist year & $2^{\text {nd }}$ year \\
\hline $\mathrm{S}_{0}$ & 11.31 & 11.09 & 3.11 & 3.18 & 1506 & 1434 & 3414 & 3083 \\
\hline$S_{1}$ & 12.11 & 12.02 & 3.19 & 3.25 & 1624 & 1464 & 3658 & 3457 \\
\hline $\mathrm{S}_{2}$ & 14.49 & 14.34 & 3.26 & 3.31 & 1867 & 1686 & 4294 & 4025 \\
\hline $\mathrm{S}_{3}$ & 18.91 & 18.73 & 3.35 & 3.37 & 1990 & 1826 & 4666 & 4281 \\
\hline $\mathrm{S}_{4}$ & 17.61 & 17.43 & 3.34 & 3.34 & 1940 & 1806 & 4390 & 4141 \\
\hline CV (\%) & 6.29 & 7.36 & 3.1 & 5.28 & 4.6 & 4.52 & 3.73 & 4.31 \\
\hline LSD (.05) & 0.62 & 0.72 & 0.08 & 0.12 & 54.83 & 49.55 & 101.71 & 109.13 \\
\hline
\end{tabular}

$\mathrm{S}_{0}=0 \mathrm{~kg} / \mathrm{ha}, \mathrm{S}_{1}=20 \mathrm{~kg} / \mathrm{ha}, \mathrm{S}_{2}=40 \mathrm{~kg} / \mathrm{ha}, \mathrm{S}_{3}=60 \mathrm{~kg} / \mathrm{ha}, \mathrm{S}_{4}=80 \mathrm{~kg} / \mathrm{ha}$ 


\section{References}

Ali, M.M., M.S.Mian, A. Islam, J.A. Begum and A.K.M.Ferdous.2004. Interaction effects of sulphur and phosphorous on wet land rice. Asian J. Pl. Sci. 3(5): 597-601.

Ali, M.H., S. M.H. Zaman and S.M.A. Hossain. 1995. Dry matter production and and distribution in plant components and its effect on seed yield of rapeseed as influenced by nitrogen, sulphur populatoin density. J.Bio. Sci. 3: 123-132.

Aulakh, M.S.,N.S. Pasricha and N.S. Sahota. 1980. Yield, nutrient and quality of mustard crop as influenced by nitrogen and sulphur fertilizers. J. Agric. Sci. Camb. 94 (1):545-549.

Begum, S. 1998. Physiological and Biochemical Studies on the low temperature tolerance in Tossa Jute (Corchorus olitorius L.). Ph. D. Thesis, Dept.of Botany, Dhaka Univ., Dhaka, Bangladesh

Dubey, O. P., T. R. Sahu, D. C. Garg and R. A. Khan. 1993. Response of mustard to S and $\mathrm{N}$ under irrigated condition. II. Effect of $\mathrm{S}$ and $\mathrm{N}$ on ancillary characters, yield and quality. J. Oilseeds Res. 10 : 11-15.

Intodia S. K. and M. P. Satu 2005. Effect of sulphur fertilization on growth of opium poppy in calcareous soils of south Rajasthan. Indian J. Pl. Physiol. 10(1):90-93.

Kaul. A, K. and M. L. Das 1986. Oilseeds in Bangladesh. Bangladesh-Canada Agriculture Sector Team, Ministry of Agriculture, Government of the people's Republic of Bangladesh. Dhaka. Pp. 42-62.

Kumawat, R.N., Rathore, P.S. and Talwar, H.S. 2005. Effect of sulphur and iron on crop growth attributes in summer green gram. Indian J. Pl. Physiol. 10 (1): 86-89.

Kumar, R., D. Singh and H. Singh. 2002. Growth and yield of Brassica species as influence by sulphur application and sowing date. Indian J. Agron. 47(3): 418 421.

Maity, S. K., G. Giri and P. S. Deshmukh. 2003. Effect of phosphorous, sulphur and planting methods on growth parameters and total yield of groundnut (Arachis hypogaea L.) and sunflower (Helianthus annuus L.). Indian J. Pl. Physiol. 8(4): 377-382.

Mohan, K. and H.C.Sharma. 1992. Effect of nitrogen and sulphur on growth, yield attributes, seed and oil yield of Indian mustard (Brassica juncea). Indian J. Agron. 37(4): $748-754$.

Mondal, M. R. I. and M. A.Wahhab. 2001. Production Technology of Oilcrops. Oilseed Research Centre, BARI, Joydebpur, Gazipur, Bangladesh. Pp. 4 -30.

Nepalia, V. 2005. Influence of weed control and sulphur on growth, yield and economics of mustard production. Res. on Crops 6 (1): 35-38.

Nasreen, S. S.M. Imamul Haq and M. Altab Hossain.2003. Effects of sulphur on growth responses and yield of onion. Asian J. Plant Sci. 2(12): 897-902. 
Rana, K.S. and D.S. Rana. 2003. Response of mustard (Brassica juncea) to nitrogen and sulphur under dryland conditions. Indian J. Agron. 48(3): 217 - 219.

Rathore, P. S. and S. S. Manohar. 1989. Response of mustard to nitrogen and sulphur.I. Effect of nitrogen and sulphur on ancillary characters and yield of mustard. Indian J. Agron. 34(3): 333-336.

Sing, H.G and M.P. Sahu. 1986. Reponse of oilseed to sulphur. Fert. News. 31: 23-30.

Singh, B. P., O. M. Prakash, B. Singh and S. K. Singh. 2002. Comparative performance of Indian mustard (Brassica juncea) genotypes in relation to sulphur fertilization. Indian J. Agron. 47(4): 531 - 536.

Steel, R. G. D. and J. H. Torrie. 1960. Principles and procedures of statistics .McGrawHill Book, Co New York, Toronto, London. Pp. 480-482.

Singh A. and N.L. Meena. 2004. Effect of nitrogen and sulphur on growth, yield attributes and seed yield of mustard (Brassica juncea) in eastern plains of Rajasthan. Indian J. Agron. 49(3): 186 - 188.

Singh, O and O. Singh. 1984.The effect of sulphur fertilization at different stages of growth, on $\mathrm{C} / \mathrm{N}$ and $\mathrm{S} / \mathrm{N}$ status of mustard (Brassica campestris L. cv. Type 42) plants. Indian J. Pl. Physiol. 27: 172-176. 